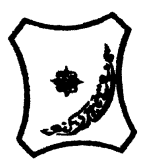

Bayero Journal of Pure and Applied Sciences, 12(1): 449 - 456

ISSN $2006-6996$

\title{
BENTHIC MACROINVERTEBRATES DIVERSITY AS BIOINDICATORS OF WATER QUALITY OF NASARAWA RESERVOIR KATSINA STATE NIGERIA
}

\author{
Zahraddeen Hassan Yusuf \\ Biology Department, Federal College of Education Katsina State, Nigeria \\ deeneecrc@gmail.com, 08036520941
}

ABSTRACT

This study was carried out to assess the water quality of Nasarawa using benthic macroinvertebrates as bioindicators. Biological monitoring working party (BMWP) scoring system was the index used to assess the ecosystem health of Nasarawa reservoir. A total of 4460 macrobenthic invertebrate comprising three phyla, three classes, six families and seventeen species were recorded. The overall macrobenthic population at the different stations revealed that the study area was dominated by Mollusca (41.18\%), Oligochaetae (23.53\%), Coleoptera and Diptera (11.77\%), Mollusca (29.06\%), Ephemerophtera and Odonata (5.89\%). (BMWP) score of 65.7 was obtained for Nasarawa reservoir which classifies the reservoir as moderately polluted. Higher BMWP score of 65.7 was recorded in the wet season compared to the dry season value of 58.7. More macrobenthic invertebrate population was recorded in the dry season than in the wet season in Nasarawa reservoir. Simpson (1-D), Shannon (H) and evenness were higher during the dry season than in the wet season but dominance was higher in the wet season. Species richness as revealed by the Margaleff and Menhinick index was higher during the wet season than in the dry season. The variations in taxa and number of individuals during the months of sampling was not significantly different $(P>0.05)$. It was found that agricultural activities, washing and bathing could alter physico-chemical parameters of the stream and hence changing the abundance of macroinvertebrates as well as the quality of water. This study, therefore, recommends that the source of pollutants should be controlled and the stream regularly monitored by the relevant authorities.

Keywords: Benthic macroinvertebrates, Bioindicator, Water quality, Reservoir

\section{INTRODUCTION}

Benthic macroinvertebrates are small aquatic animals and the aquatic larval stages of insects. Macroinvertebrates respond to human disturbance in fairly predictable ways, they are relatively easy to identify in the laboratory, often live for more than a year and, unlike fish, have limited mobility. In fact, because they cannot escape pollution, macroinvertebrates have the capacity to integrate the effects of the stressors to which they are exposed, in combination and over time. Macroinvertebrate communities therefore reside in an aquatic system long enough to reflect the chronic effects of pollutants, and yet short enough to respond to relatively acute changes in water quality. Unlike fish, these populations tend to be relatively immobile, and as a result are continuously exposed to the constituents of the surface water they inhabit. Thus, because of the limited mobility of macroinvertebrates and their relative inability to move away from adverse conditions, the location of chronic sources of pollution often can be pinpointed by comparing communities of these organisms. Macroinvertebrates exhibit varying responses to changes in water chemistry, water quality and physical habitat. Each macroinvertebrate's response to environmental perturbations produces measurable, and often predictable, shifts in abundance and composition at the community level (EPA, 2016). The Biological Monitoring Working Party (BMWP) assigns scores to each macroinvertebrate taxon according to their responses to oxygen deficits caused by organic pollution. The analysis of these pollution induced responses allows the calculation of sensitivity values by the different groups of organisms (Hawkes, 1998). Macroinvertebrates, which were utilized in aquatic pollution studies, include: Mayflies (Ephemeroptera), caddisflies (Trichoptera), stoneflies (Plecoptera), beetles (Coleoptera), crayfish and amphipods (Crustaceans), aquatic snails (Mollusca), biting midges (Chironomids) and leeches (Hirudinea) in Nigeria, North America and Europe (Tampus et al., 2012). 
Special Conference Edition, November, 2019

Research reports on the use of macroinvertebrates to assess the water quality in aquatic ecosystems have been extensively published by several researchers (Ogbeibu, \& Oribhabor, 2002). On the other hand to the best of my knowledge limited studies were found in literature utilizing the application of the benthic macroinvertebrates to evaluate the reservoir water quality in Katsina state, Nigeria and particularly in Nasarawa reservoir. In view of this therefore this study aim of the present study is to of Water Quality of Nasarawa Reservoir
Katsina State Nigeria using Benthic Macroinvertebrates Diversity as Bioindicators.

\section{MATERIALS AND METHODS \\ Study Area}

Nasarawa reservoir is located at latitude $12^{\circ} 59$ minutes and 33 seconds North and longitude $7^{\circ}$ 30 minutes and 48 seconds East (Fig 1) in Nasarawa village Jibia Local Government Katsina State. Majority of the people in Nasarawa village were farmers and local fishermen that rely much on the reservoir for their irrigation and fishing activities as their means of livelihood.

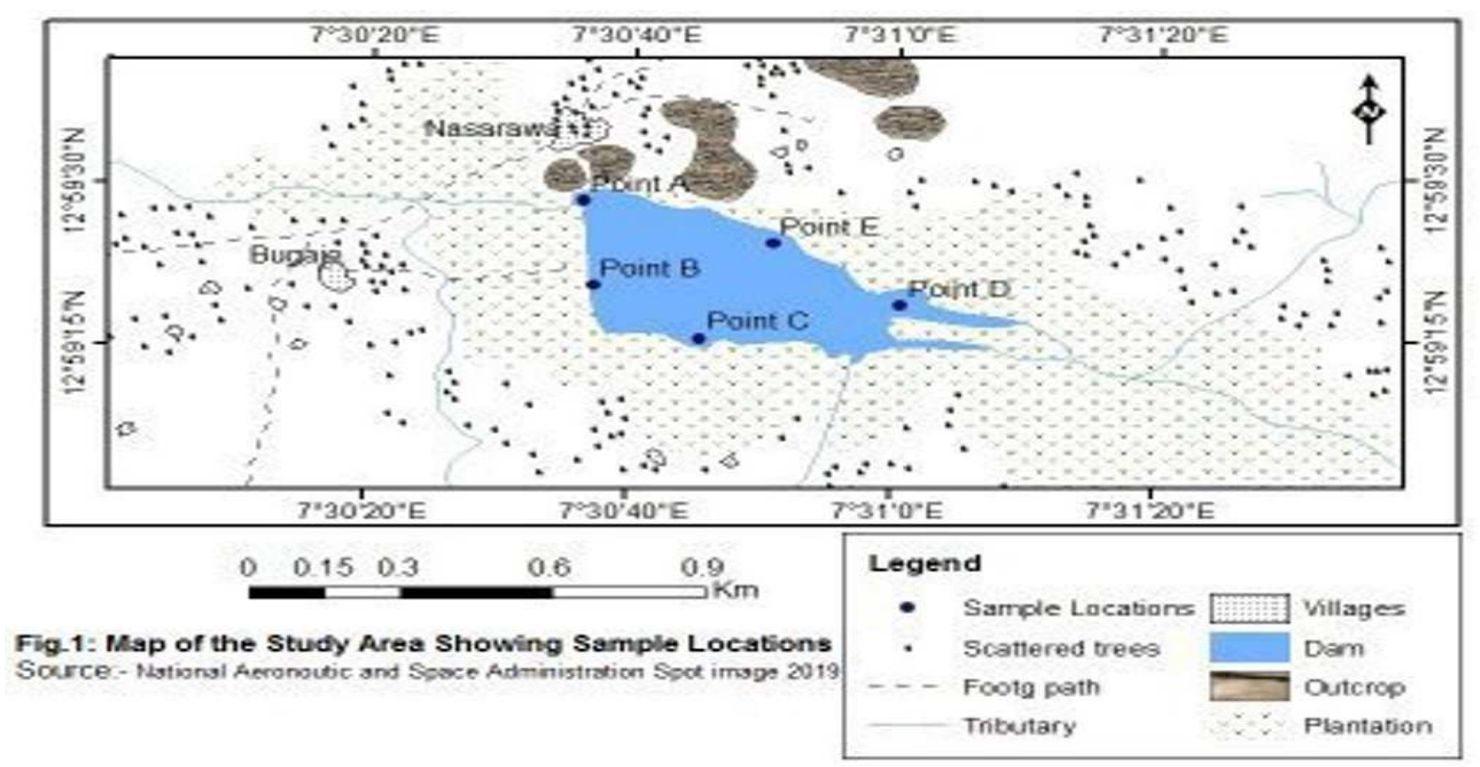

Figure 1: Map of Nasarawa Reservoir Showing the Sampling Points ((Source: Cartography Lab. Geography Dept. Umaru Musa Yar'adua Univeristy Katsina, 2019).

\section{Sampling Sites}

From the preliminary visit to the reservoir, five sampling sites were established for the purpose of sample collection. The activities taking place at each site were taking into consideration. The sites are decribed as follows:

Site 1: This the dam spill way site located at lat $13^{\circ} 59^{\prime} 37^{\prime \prime} \mathrm{N}$ and $7^{\circ} 30^{\prime} 40^{\prime \prime} \mathrm{E}$. The major activities at this sire are washing and drinking by the community members. The area is also rich in aquatic macrophytes.

Site 2: This is area with very little or no human activities, located at lat $13^{\circ} 59^{\prime} 24^{\prime \prime} \mathrm{N}$ and $7^{\circ} 30^{\prime}$ 42" E.

Site 3: This site is located at lat $13^{\circ} 59^{\prime} 13^{\prime \prime} N$ and $7^{\circ} 31^{\prime} 01^{\prime \prime} \mathrm{E}$. The activities at this site includes intense farming and irrigation activities. Water for domestic and livestock use is also collected from this site.

Site 4: This is a site through which water from the catchment area (river tarwatsi) enters into the reservoir. Its located at lat $13^{\circ} 59^{\prime} 15^{\prime \prime} \mathrm{N}$ and $7^{\circ} 31^{\prime} 29^{\prime \prime} \mathrm{E}$.
Site 5: Located at lat $13^{\circ} 59^{\prime} 33^{\prime \prime} N$ and $7^{\circ} 31^{\prime}$ $05^{\prime \prime} \mathrm{E}$. Moderate irrigation activities and livestock feeding takes place in this site.

\section{Benthic Macroinverterbrates Collection}

Samples were collected from bottom sediments in the all sampling stations. This was accomplished with the use of rectangular framed

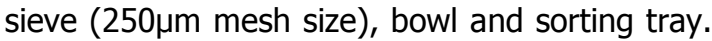
Here the bowl was used to collect the sediments together with the water and poured into the rectangular frame and then sieved. The contents were transferred in sorting trays to ease separating the macroinvertebrates from other particles. The samples collected were transferred into specimen bottles, and immediately fixed in the field with $10 \%$ formalin and also subsequently preserved in $70 \%$ ethyl alcohol (Kalyoncu \& Zeybek, 2010). A standard identification chart (Identification guide to freshwater macroinvertebrates) was used to classify the sample into various taxa and species (Gill, 2011). 
Special Conference Edition, November, 2019 Each family of macroinvertebrates sampled at each site was allocated the Biological Monitoring Working Paper (BMWP) score according to their sensitivity/tolerance to physico-chemical parameters. Each score for each family represented in the sample for sites, was summed to generate the BMWP score (Walley \& Hawkes 1997).

Community Structure Analysis for Benthic Macroinvertebrates

Menhinick's index, Margalef index, Shannon and Weaver diversity index, Simpson diversity index, evenness were determined using the PAST software

\section{Data Analysis}

Any significant differences between seasons was tested using $\mathrm{T}$ test while spatial and monthly variations were assessed using one way analysis of variance (ANOVA).

\section{RESULTS}

A total of 4460 macrobenthic invertebrate comprising three phyla, three classes, six families and seventeen species were recorded. These include one genus each of Odonata and Ephemerophtera, two genus each of Coleoptera and Diptera, four genera each of Oligochaeta and seven genera each of Mollusca. A summary of the relative percentage composition of the major taxonomic groups to the overall macrobenthic population at the different stations revealed that the study area was dominated by Mollusca (41.18\%), Oligochaetae (23.53.56\%), Coleoptera and Diptera (11.77\%), Mollusca (29.06\%), Ephemerophtera and Odonata (5.89\%) (Table 1).

Table 1: Benthic macroinvertebbrate Composition, Relative Abundance and BMWP score in Nasarawa reservoir Jibia L.G Katsina State (Feb 2018- Nov. 2018)

BMWP Key: 0-10 Very poor Heavily polluted; 11-40 Poor Polluted or impacted ; 41-70 Moderate

\begin{tabular}{|c|c|c|c|c|c|c|c|}
\hline Taxon & $\begin{array}{l}\text { Site } \\
\text { A }\end{array}$ & Site B & Site C & $\begin{array}{l}\text { Site } \\
\text { D }\end{array}$ & Site E & Total & $\begin{array}{l}\text { R. } \\
\text { Abundance } \\
(\%)\end{array}$ \\
\hline \multicolumn{8}{|l|}{ Coleoptera(11.77\%) } \\
\hline Onychohydrus sp & 0 & 0 & 74 & 86 & 0 & 160 & 3.59 \\
\hline Hydrophylus sp & 36 & 0 & 68 & 72 & 0 & 176 & 3.95 \\
\hline Diptera(11.77\%) & & & & & & & 0.00 \\
\hline Chironomus sp & 54 & 52 & 64 & 59 & 56 & 285 & 6.39 \\
\hline Tanytarsus sp & 34 & 28 & 45 & 40 & 38 & 185 & 4.15 \\
\hline Ephemeroptera(5.89\%) & & & & & & & 0.00 \\
\hline Caenis sp & 4 & 0 & 6 & 0 & 3 & 13 & 0.29 \\
\hline Mullusca(41.18\%) & & & & & & & 0.00 \\
\hline Anadonta anatine & 0 & 24 & 32 & 14 & 0 & 70 & 1.57 \\
\hline Anadonta cygnea & 0 & 25 & 31 & 10 & 0 & 66 & 1.48 \\
\hline Bulinus sp & 44 & 28 & 43 & 36 & 49 & 200 & 4.48 \\
\hline Cleopatra bulimoides & 8 & 4 & 13 & 12 & 10 & 47 & 1.05 \\
\hline Lymanea natalensis & 142 & 165 & 182 & 160 & 174 & 823 & 18.45 \\
\hline Melanoides tubaculata & 268 & 284 & 386 & 286 & 348 & 1572 & 35.25 \\
\hline Physa sp & 8 & 6 & 9 & 7 & 4 & 34 & 0.76 \\
\hline Odonata(5.89\%) & & & & & & & 0.00 \\
\hline Lestes sp & 2 & 0.00 & 4 & 0.00 & 0.00 & 6 & 0.13 \\
\hline Oligochaetae(23.53\%) & & & & & & & 0.00 \\
\hline Diplogaster sp & 0 & 0 & 8 & 6 & 4 & 18 & 0.40 \\
\hline Eisenniella sp. & 28 & 18 & 68 & 30 & 31 & 175 & 3.92 \\
\hline Lumbriculus sp & 32 & 46 & 64 & 68 & 30 & 240 & 5.38 \\
\hline Tubifex sp & 42 & 98 & 92 & 76 & 82 & 390 & 8.74 \\
\hline $\begin{array}{l}\text { Total } \\
\text { BMWP Score }\end{array}$ & 702 & 778 & 1189 & 962 & 829 & 4460 & $\begin{array}{l}100.00 \\
65.7\end{array}$ \\
\hline
\end{tabular}


Special Conference Edition, November, 2019

Moderately impacted; 71-100 Good Clean but slightly impacted; >100 Very good unpolluted, unimpacted

The community structure index of benthc macrobenthic invertebrates in wet and dry season of Nasarawa reservoir is presented in Table 3. For species diversity, Simpson (1-D),
Shannon $(\mathrm{H})$ and evenness were higher during the dry season than in the wet season but dominance was higher in the wet season. Species richness as revealed by the Margaleff and Menhinick index was higher during the wet season than in the dry season (Table 2).

Table 2: Benthic macroinvertebrate Composition and Community Structure during Wet and Dry season in Nasarawa Reservoir

\begin{tabular}{|c|c|c|c|}
\hline Species Composition & $\begin{array}{l}\text { Dry } \\
\text { season(\%) }\end{array}$ & $\begin{array}{l}\text { Wet } \\
\text { season } \\
(\%)\end{array}$ & Total \\
\hline \multicolumn{4}{|l|}{ Taxon } \\
\hline \multicolumn{4}{|l|}{ Coleoptera } \\
\hline Onychohydrus sp & $110(5.1)$ & $50(2.17)$ & 160 \\
\hline Hydrophylus sp & $121(5.61)$ & $55(2.39)$ & 176 \\
\hline \multicolumn{4}{|l|}{ Diptera } \\
\hline Chironomus sp & $105(4.87)$ & $180(7.82)$ & 285 \\
\hline Tanytarsus sp & $75(3.48)$ & $110(4.78)$ & 185 \\
\hline \multicolumn{4}{|l|}{ Ephemeroptera } \\
\hline Caenis sp & 0 & $13(0.56)$ & 13 \\
\hline \multicolumn{4}{|l|}{ Mullusca } \\
\hline Anadonta anatina & $46(2.13)$ & $24(1.04)$ & 70 \\
\hline Anadonta cygnea & $38(1.76)$ & $28(1.22)$ & 66 \\
\hline Bulinus sp & $88(4.08)$ & $112(4.87)$ & 200 \\
\hline Cleopatra bulimoides & $12(0.56)$ & $35(1.52)$ & 47 \\
\hline Lymanea natalensis & $303(14.04)$ & $520(22.59)$ & 823 \\
\hline Melanoides tubaculata & $672(31.14)$ & $90039.10)$ & 1572 \\
\hline Physa sp & $15(0.70)$ & $19(0.83)$ & 34 \\
\hline \multicolumn{4}{|l|}{ Odonata } \\
\hline Lestes sp & $4(0.19)$ & $2(0.09)$ & 6 \\
\hline \multicolumn{4}{|l|}{ Oligochaetae } \\
\hline Diplogaster sp & $15(0.70)$ & $3(0.13)$ & 18 \\
\hline Eisenniella sp. & $115(5.33)$ & $60(2.61)$ & 175 \\
\hline Lumbriculus sp & $144(6.67)$ & $96(4.17)$ & 240 \\
\hline Tubifex sp & $295(13.67)$ & $95(4.13)$ & 390 \\
\hline Total & & & 4460 \\
\hline BMWP & 58.7 & 67.5 & \\
\hline Taxa_S & 16 & 17.00 & \\
\hline Dominance_D & 0.1545 & 0.22 & \\
\hline Simpson_1-D & 0.8455 & 0.7778 & \\
\hline Shannon_H & 2.218 & 1.96 & \\
\hline Evenness_e $e^{\wedge} H / S$ & 0.5744 & 0.42 & \\
\hline Menhinick & 0.3444 & 0.36 & \\
\hline Margalef & 1.954 & 2.07 & \\
\hline
\end{tabular}


Special Conference Edition, November, 2019

Although Simpson (1-D), Shannon (H) diversity was higher at site $B$ and $C$; evenness was higher at site D. Dominance was higher at site $E$, followed by site A and B. Species richness as revealed by the Margaleff and Menhinick index was higher at site $C$ followed by site $D$ and lowest at site E (Table 3). The Biological Monitoring Working Paper (BMWP) score of 65.7 was obtained for Nasarawa reservoir (Table 2). This classifies the reservoir as moderately polluted. Higher BMWP score of 65.7 was recorded in the wet season compared to the dry season value of 58.7. Spatially a BMWP score of 40.6, 49.1, 65.7, 51 and 44.9 was recorded in site $A, B, C, D$ and respectively. ANOVA (Appendix 1) revealed that the variations in taxa and number of individuals during the months of sampling was not significantly different $(P>0.05)$. There is no significant difference $(P>0.05)$ in the seasonal abundance of benthic macroinvertebrates of Nasarawa reservoir (Appendix2).

Table 3: Community Structure Indices and BMWP score for the Benthic Macroinvertebrates of Nasarawa Reservoir Jibia Local Government, Katsina State

\begin{tabular}{lrrrrr}
\hline Diversity Index & \multicolumn{1}{c}{ Site A } & \multicolumn{1}{c}{ Site B } & \multicolumn{1}{c}{ Site C } & \multicolumn{1}{c}{ Site D } & \multicolumn{1}{c}{ Site E } \\
\hline Taxa_S & 13.00 & 12.00 & 17.00 & 15.00 & 12.00 \\
Individuals & 702.00 & 778.00 & 1189.00 & 962.00 & 829.00 \\
Dominance_D & 0.21 & 0.21 & 0.16 & 0.15 & 0.24 \\
Simpson_1-D & 0.79 & 0.79 & 0.84 & 0.85 & 0.76 \\
Shannon_H & 1.95 & 1.92 & 2.27 & 2.22 & 1.78 \\
Evenness_e^H/S & 0.54 & 0.57 & 0.57 & 0.62 & 0.49 \\
Menhinick & 0.49 & 0.43 & 0.49 & 0.48 & 0.42 \\
Margalef & 1.83 & 1.65 & 2.26 & 2.04 & 1.64 \\
BMWP Score & 40.6 & 49.1 & 65.7 & 51 & 44.9 \\
\hline
\end{tabular}

BMWP Key: 0-10 Very poor Heavily polluted; 11-40 Poor Polluted or impacted; 41-70 Moderate Moderately impacted; 71-100 Good Clean but slightly impacted; >100 Very good Unpolluted, unimpacted.

\section{DISCUSSION}

During the present investigation, it was observed that at almost all the sites the maximum species were recorded during dry season period (Yusuf, 2020) when temperature is usually low and the amount of dissolved oxygen is more (Negi \& Sheetal, 2013). The maximum density of benthic fauna observed during dry season can be related to the availability of phytoplankton population in the form of food supply as also observed by Joshi et al., (1996). During the dry season the organic matter washed by rain is processed by bacterial decomposition, thus liberating the fine particulate organic matter into the system, which is the main food resource of the Chironomidae. Thus the water flow and temperature influences the amount of available food, promoting the release and removal of nutrients (Oliveira \& Nessimian 2010). The decline in the density of benthic fauna during rainy season months may be due to increase load of suspended solids, reduced transparency and increased water flow. Similar findings have also been observed by many workers (Duffield \& Nelson, 1993). Oligochaeta can also be described as deposit feeders, as such more tolerant to silting and decomposition than other groups of benthic organisms (Olumukoro \&
Victor, 2001). Oligochaetae were found to be dominating benthic macroinvertebrate assemblage because they can tolerate low dissolved oxygen due to their cutaneous respiration (Mandaville, 2002). Strzelec and Krolczyk (2004) indicated that many gastropod species are tolerance to many physico-chemical parameters and their occurrence is affected by the quality of bottom sediments and abundance of vegetation and most suitable substrate for snail in water is a sandy bottom covered with thin layer of organic silt. Likewise presence of Melanoides tuberculata is well known as a species that can tolerate the presence of low dissolved oxygen and high suspended particulate matter in river's water (Sastrawijaya, 1991). Gastropod especially Melanoides is very abundant in waters affected by agricultural waste even at low level of dissolved oxygen (Patang et al., 2018). M. tuberculata is tolerant not only in oligotrophic ecosystems (Patang et al., 2018) but also in ecosystem contaminated by low level of organic matter (Rehn, 2009). $M$. tuberculata likes the temperature in the range of $18-32^{\circ}$ C. M. tuberculata has an operculum and thick shell that can protect itself from drought so that it can survive on dry land and high salinity (Mitchell et al., 2007). 
Special Conference Edition, November, 2019

In addition, operculum also serves to increase their tolerance to toxic chemicals in the environment. So, these taxa are recommendable to be used as a bioindicator of polluted ecosystems (Mitchell et al., 2007). Dipterans were found to be abundant in all the sampling sites. This coincides with report of Mbah and Vajime, (1989) that the dominance of dipterans in the system as in other aquatic ecosystems may be attributed to their morphological and physiological adaptations to the various habitats, availability of food and sustained reproduction. Chironomus sp larva is a species indicator of waters contaminated by high load of organic waste. In fact, it can live in waters even at low oxygen levels (Sastrawijaya, 1991). Chironomids which were among the invertebrates that accounted most in the overall abundance of the dipterans are known to colonize all kinds of environments including polluted waters. They hardly show any habitat restriction (Victor and Ogbeibu, 1991) and are known to replace other invertebrate taxa in streams perturbed by human activity. Shannon-Weiner diversity index values above 3.0 indicate that the structure of the habitat is stable, while values less than 1.0 indicate that there are pollution and degradation of the habitat structure (Mandaville, 2002). Margalef's water quality index values greater than 3.0 indicate clean conditions, values less than 1.0 indicate severe pollution and intermediate values indicate moderate pollution (Lenat et al., 1980). Based on the community structure analysis of benthic macroinvertebrates conducted in this study, Nasarawa reservoir can be regarded as being polluted and having poor habitat structure at the sampling sites. The overall diversity index values also suggest that the reservoir was moderately polluted. Individual animals were evenly distributed in a moderate fashion within the sampling sites since Pielou's evenness index values closer to 1 indicates more evenness (Pielou, 1966). The recorded seasonal and spatial variation in community structure could be related to seasonal differences in habitat characteristics with respect to physicochemical and biotic influences. The variations could directly or indirectly affect the sediment stability through sediment mixing, exposure to water level fluctuations and changes in the sediment chemistry. Reice (1980) observed that invertebrate biomass, density and richness increase with habitat diversity and substrate size. The low species diversity could be due to the acidic nature of the sediment as shown by the lower $\mathrm{pH}$ values during the rainy season. The low transparency during the rainy season due to increased sedimentation may account for their low diversity in the wet season.
Doeg et al., (1987) reported that increased sedimentation reduced the total number of macroinvertebrates species. The present study indicates that benthic community structure and diversity of Nasarawa reservoir depends upon seasonal changes in both abiotic (Yusuf, 2020) and biotic components of the reservoir. The rocky nature of site $A$ might be the reason the low species diversity and richness recorded in the site, as some benthic maroinvertebrates burrow in the water surface to avoid being washed away when it's raining and inflow increases (Stahley, 2011). Substrate has a direct influence on macrobenthic organisms by diminishing or increasing their ability to adhere, dig, escape from predators, provide protection from current, find shelter, or lay eggs; it can moreover act indirectly by influencing the advantage of inhabiting a particular microhabitat. (Mackay, 1992). Townsend (1980) reported that nature of the substratum is another factor that affects benthic macroinvertebrates diversity. The cumulative BMWP score during the study period was 65 . Based on this score Nasarawa reservoir belong to class III (41 - 70) category of 'Questionable' interpreting a moderately polluted water body. The BMWP scores (49.1, 65.7, 51, 44.9 for site $B, C, D$ and $E$ respectively) during the sampling period were categorized to have an "evident effect of contamination; moderate water quality", according to the index. On the other hand, the score of 40.6 for site A was categorized as "contaminated water, bad water quality", according to the index. This may be due to the intense human activities at the site.

\section{CONCLUSION}

The benthic macroinvertebrates in Nasarawa reservoir were dominated by Chironomus $s p$ and Melanoides tuberculata which are clearly indicated. These two taxa are quite sensitive to water quality degradation. The results of the biological monitoring working party (BMWP) for ten months, shows that sampling sites $B, C, D$, and $E$ are moderately polluted while site $A$ was characterised as contaminated water, bad water quality. Factors which influenced the abundance and distribution of benthic macroinvertebrates include the nature of the water body, habitat richness and stability, primary productivity, and anthropogenic activities. The information obtained is crucial in serving as baseline data for various agencies, including governmental, academic and nongovernmental institutions, to take actions for more efficient sustainable management of this reservoir in particular and others in the country in general. 
Special Conference Edition, November, 2019 REFERENCES

Doeg, T. J., Davey, G. W., \& Blyth, J. D. (1987). Response of the aquatic macroinvertebrate communities to dam construction on the Thomson River, southeastern Australia. Regulated Rivers: Research \& Management, 1(3), 195-209.

Duffield RM., \& Nelson, C.H. (1993). Seasonal changes in the stonefly (Plecoptera), copmponent of the diet profile of trout in Hunting Creek, Maryland, USA. Aquatic Insects, 15, $141-8$.

Environmental Protection Agency. (2016). Indicators: Benthic Macroinvertebrates Retrieved from https://www.epa.gov/national-aquaticresource-surveys/indicators-benthic macroinvertebrates

Gill, K. (2011). Identification Guide to Freshwater Macroinvertebrates. Retrieved November 18, 2018, from https://stroudcenter.org/wpcontent/uploads/MacroKey_Complete.pd $f$.

Hawkes, H. A. (1998). Origin and development of the biological monitoring working party score system. Water Research, 32(3), 964-968.

Joshi, B.D., Bisht R.C.S., Joshi, N., \& Singh, R. (1996). A study of planktonic and benthic components of three selected tributaries of river Ganga between Devprayag and Rishikesh. Him. Journal Environmental Zooology, 10, $23-6$.

Kalyoncu, H., and Zeybek, M. (2010). An application of different biotic and diversity indices for assessing water quality. African Journal of Agricultural Research, 6(1), 19-27.

Lenat D. R., Smock L. A. and Penrose D. L. (1980). Use of benthic macroinvertebrates as indicators of environmental quality. In Biological monitoring for environmental effects. (L. W. Douglass, ed.), pp. 97114.LexingtonBooks, Toronto.

Mbah, C. E., \& Vijime, C. G. (1989). Preliminary Taxonomic survey of fresh water insects from northern Nigeria. Journal of Aquatic Sciences, 4, 27-39.

Mackay, R.J. 1992. Colonization by lotic macroinvertebrates: a review of processes and

patterns. Canadian Journal of Fisheries and Aquatic Science. 49, 617-628.

Mandaville, S. M. (2002). Benthic macroinvertebrates in freshwaters: Taxa tolerance values, metrics, and protocols (pp. 21-38). Nova Scotia: Soil \& Water Conservation Society of Metro Halifax.

Mitchell, A. J., Hobbs, M. S., \& Brandt, T. M. (2007). The effect of chemical treatments on red-rim melania Melanoides tuberculata, an exotic aquatic snail that serves as a vector of trematodes to fish and other species in the USA. North American Journal of Fisheries Management, 27(4), 12871293.

Negi, R. K., \& Mamgain, S. (2013). River of Garhwal Himalaya Uttarakhand. Pakistan Journal of Biological Sciences, 16(22), 1510-1516.

Ogbeibu, A. E., \& Oribhabor, B. J. (2002). Ecological impact of river impoundment using benthic macro-invertebrates as indicators. Water research, 36(10), 2427-2436.

Oliveira, A. \& Callisto, M. (2010). Benthic macroinvertebrates as bioindicators of water quality in Atlantic forest fragment. Iheringia, Série Zoologia 100:291-300

Oliveira, A.L.H. \& Nessimian, J.L. 2010. Spatial distribution and functional feeding groups of aquatic insect communities in Serra da Bocaina streams, southeastern Brazil. Acta Limnologica. Brasilensia. 22, 424-441. http://dx.doi.org/10.4322/actalb.2011.0 07

Olomukoro J. O., and Victor R. (2001). The distributional relationship between the macrobenthic invertebrate fauna and Particulate Organic matter in a small tropical stream. Tropical Journal of Environment, Science and Health 2(1), 58-64.

Patang, F., Soegianto, A., \& Hariyanto, S. (2018). Benthic macroinvertebrates diversity as bioindicator of water quality of some rivers in East Kalimantan, Indonesia. International Journal of Ecology, 2018.

Pielou, E. C. (1966). The measurement of diversity in different types of biological collections. Journal of Theoretical Biology, 13, 131-144.

Rehn, A. C. (2009). Benthic macroinvertebrates as indicators of biological condition below hydropower dams on west slope Sierra Nevada streams, California, USA. River Research and Applications, 25(2), 208-228.

Reice, S. R. (1980). The role of substratum in benthic microdistribution and litter 
Special Conference Edition, November, 2019

decomposition in a woodland stream. Ecology, 61(3), 580-590.

Sastrawijaya, A. T. (1991) Environmental Pollution, Rineka Cipta Publishres, Jakarta, Indonesia,.

Strezelec, M. \& Krolczyk, A. (2004) Factors Affecting Snail (Gastropoda) Community Structure in the Upper Course of the Warta River (Poland). Biologia Bratislava, 59(2), 159-163.

Stahley, A., \& Kodani, C. H. (2011). Assessing Small Streams in the Upper Ocmulgee Watershed Using the Georgia Adopt-aStream Macroinvertebrate Monitoring Protocols. Georgia Journal of Science, 69(2), 6.

Tampus, A. D, Tobias E. G, Amparado, R.F, Bajo, L and Sinco A. L. (2012). Water quality assessment using macroinvertebrates and physicochemical parameters in the riverine system of Iligan city, Philippines. Advances in

Environmental Sciences (AES) International Journal of the Bioflux Society, 4(2), 59-68.

Townsend, C. R. (1980). The ecology of streams and rivers. Edward Arnold Publishers Itd, London 219-221

Victor, R. \& Ogbeibu, A.E. (1991). Macro invertebrates' communities in the erosional biotopes of an Urban stream in Nigeria. Tropical Zoology. 4, 1-12

Walley, W.J., \& Hawkes H.A., (1997). A computer-based development of the Biological Monitoring Working Party score system incorporating abundance rating, biotope type and indicator value. Water Research, 31 (2), 201-210.

Yusuf, Z.H. (2020). Phytoplankton as bioindicators of water quality in Nasarawa reservoir, Katsina State Nigeria. Acta Limnologica Brasiliensia, , $32(4), 1-10$.

Appendices

Appendix 1: Analysis of Variance for Benthic Macroinvertebrates in Nasarawa Reservoir

\begin{tabular}{|c|c|c|c|c|c|c|}
\hline & $\begin{array}{l}\text { Sum of } \\
\text { sqrs }\end{array}$ & Df & & $\begin{array}{l}\text { Mean } \\
\text { square }\end{array}$ & $\mathrm{F}$ & p (same) \\
\hline \multirow{2}{*}{$\begin{array}{l}\text { Between } \\
\text { months: } \\
\text { Within } \\
\text { months: }\end{array}$} & 10873.3 & & 9 & 1208.15 & \multirow{3}{*}{$\begin{array}{l}0.09717 \\
\text { Permutation } p \\
(n=99999)\end{array}$} & \multirow{3}{*}{ p 0.9996} \\
\hline & 621654 & & 50 & 12433.1 & & \\
\hline Total: & 632527 & & 59 & 0.9996 & & \\
\hline
\end{tabular}

Appendix 2: $T$ test for the Seasonal Abundance of the Benthic Macroinvertebrates in Nasarawa Reservoir

Tests for equal means

Dry

$\mathrm{N}$ :

Mean:

95\% conf.:

Variance:

Difference between means:

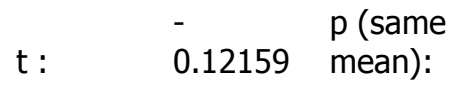

Uneq. var. $\mathrm{t}$ :

Monte Carlo permutation:
Wet

$17 \mathrm{~N}$

17

127 Mean:

135.41

$(41.205$

212.8)

95\% conf.:

(16.473 254.35)

27845 Variance:

53514

8.4118

0.90398

-0.12159 mean):

$\mathrm{p}$ (same

mean): 0.9188
0.90406 